\title{
The Function of the Judge and Jury in the "Literary Property" Lawsuit
}

\author{
William B. Carman*
}

THERE HAS been comparatively little discussion of the diverse functions of the court and jury in cases involving plagiarisin or other actions dealing with the ownership and infringement of rights in intellectual compositions. By far the great majority of cases of this nature have been tried initially by a court sitting without a jury. This may have been due to the fact that under the Copyright $\mathrm{Law}$ there are specific equitable remedies provided which have been customarily invoked by plaintiffs. It may also have been due to the desire of counsel for both parties to submit technical copyright issues to a court rather than a jury. Until recently at least, the majority of all the cases involving this type of property have been brought under the Federal Copyright Law rather than under any claim of common law rights. ${ }^{1}$

Regardless of the reasons, the fact remains that heretofore most decisions have presented situations wherein the court acted not only as the arbiter of the law, but as the trier of the facts; consequently, there is a marked paucity of authority discussing the lines to be drawn between socalled "issues of law and fact." 2 Recently, however, especially in California, jury trials have been demanded in almost every case. For that reason it is believed a discussion of this almost uncharted field is appropriate.

It is first valuable to determine the usual issues in the ordinary case involving literary property. Almost every action for plagiarism will require the determmation of the following issues:

(1) What material in plaintiff's work is capable of legal protectibility, i.e., may constitute "property"?

(2) To what extent is such property the product of plaintiff's own independent creative effort?

* Member, Los Angeles Bar.

1 It is interesting to note that in California, the center of the motion picture, radio and television industries, no decision had been rendered by the Supreme Court in this field prior to Stanley v. Columbia Broadcasting System, 35 Cal.2d 653, 221 P.2d 73 (1950) and Golding v. R.K.O. Pictures, 35 Cal.2d 690, 221 P.2d 95 (1950), excepting the narrow technical discussion in Loew's Inc. v. Superior Court, 18 Cal.2d 419, 115 P.2d 983 (1941). In fact, the only cases in the Courts of Appeal which involved any general discussion of principles were Barsha $v$. M-G-M, 32 Cal. App.2d 556, 90 P.2d 371 (1939), Yadkoe v. Fields, 66 Cal. App.2d 150, 151 P.2d 906 (1944) and Johnston v. Twentieth Century-Fox, 82 Cal. App.2d 796, 187 P.2d 474 (1947). But cf., Melvin v. Reid, 112 Cal. App. 285, 297 Pac. 91 (1931); Metter v. Los Angeles Examiner, 35 Cal. App.2d 304, 95 P.2d 491 (1939).

2 The question of the province of judge and jury is briefiy adverted to in a most excellent Note by Manuel Furtado in 38 CaIIF. L. REv. 332 (1950). 
(3) Are there substantial similarities between defendant's work and such of the property in plaintiff's work as was independently conceived by him?

(4) If so, are such similarities the result of copying by the defendant? (a) Did defendant have the possibility of access to plaintiff's work? (b) If so, did he actually see and use plaintiff's work, or are the similarities to plaintiff's independently conceived property due to defendant's use of other sources, or to coincidence?

(5) If defendant has copied and used plaintiff's independently conceived property, what damage has plaintiff suffered?

Individual cases may present other issues, ${ }^{3}$ but the foregoing will be almost universally existent.

Where there have been negotiations or similar relationships between plaintiff and defendant, it has been customary to add a count in express or implied in fact contract. With respect to such count, there will ordinarily be the following issues presented:

(1) Was there a factual agreement of any sort reached between the parties?

(2) If so, what was the nature of that agreement?

(3) Was the agreement breached by the defendant?

(4) If so, what are the damages?

In deterımining these issues under a contract count there will almost invariably have to be determined issues concerning similarity and copying. Furthermore, in the ordinary case the determination of the extent of the "property" interest in plaintiff's work, and whether or not it was independently conceived, will be important to the determination of the existence or nonexistence of a contract, its nature and the amount of damages. Also, in many cases the question as to whether plaintiff's material is new or novel regardless of its independent conception becomes iniportant to the same determinations. It is the purpose of this article to consider both $a$ priori and with reference to available authorities the functions of the judge and jury in determining these issues. ${ }^{4}$

3 E.g., has the material been reduced to concrete form, Golding v. R.K.O. Pictures, 35 Cal.2d 690, 695, 221 P.2d 95, 98 (1950) (for the court); has it been previously "published" or "made public," Stanley v. Columbia Broadcasting System, 35 Cal.2d 653, 666, 221 P.2d 73, 81 (1950) (for the court, on uncontradicted facts); plaintiff's technical title or right to the work; the technical validity of any copyrights; unprotectibity by reason of obscenity or other public violations; existence or nonexistence of license or authority to use from plaintiff; statutes of limitations, Italiani v. M-G-M, 45 Cal. App.2d 464, 114 P.2d 370 (1941).

4 In the ensuing discussion, no distinction is made between cases arising under the Federal Copyright Law and those arising at conmon law. Regardless of the often-quoted statement from Corpus Juris that "common law rights in unpublislied works are of wider and more exclusive nature than the riglits conferred by statutory copyright in published works," it is believed that there is no distinction between statutory and common law "copyright" as to the 


\section{TORT}

\section{The Issue of Protectibility With Respect to the Nature of the Material}

The law by no means affords protectibility to everything which is contained in a "composition in letters or art." Only to the extent that it does so may there be "literary property" capable of ownership on the one hand, and of tortious misappropriation on the other. The concepts of protectibility and of property are peculiarly legal concepts. Protectibility relates to the extent to which the law grants remedies for the infringement of rights which the law has declared to exist; property is the aggregate of rights which are guaranteed and protected by the law..$^{8}$ Consequently, it is for the court, not only in the first imstance but ultimately, to determine what is and what is not protectible - what is and what is not property - in plaintiff's work.

To the extent that there might be conflicting substantial evidence as to any fact upon which the application of the law depends, the court will, as always, submit the determination of such fact to the jury under appropriate instructions. Where no such conflict exists, there is no function for the jury. The existence and extent of plaintiff's property in any literary work depends upon two facts: (a) The nature of the material itself, and (b) independent authorship of that material by the plaintiff. There may be a conflict of evidence as to the latter; there can be none as to the former.

Any work is, of course, the sole evidence of its contents. It is entire, indisputable and unchangeable. Just as it is the function of the court and not of the jury to determine and delineate the legal rights arising from any written document, such as a contract, deed or will, ${ }^{7}$ so it would seem to be the function of the court to determine and delineate the legal rights inherent in the literary work - the extent to which property exists or does not exist therein. The initial function of the court in a literary property case, therefore, is to dissect the plaintiff's work and determine, concretely and not abstractly, what particnlar elements plaintiff may claim as protectible and what lie may not. ${ }^{8}$

elements of protectibility, authorship, similarity and copying. The statement is probably correct only as involving the issue of "fair use," i.e., the right to use protectible material covered by statutory copyright for purposes of criticism, comment, etc. Cf. Karll v. Curtis Pub. Co., 39 F. Supp. 836 (D. Wis. 1941) ; Broadway Music Corp. v. F-R Pub. Corp., 31 F. Supp. 817 (S.D. N.Y.1940).

5 CaI. Civ. Code $\$ 980$, as amended in 1947; Amour, Copyrigetr Law 5-18 (1936).

6 Fnlton Light, Heat \& Power Co. v. State, 65 Misc. 263, 121 N.Y. Supp. 536 (Ct. Cl. 1909); Brown, Personal Property 6 (1936). Black, Law Dictionary "Property."

7 O'Connor v. West Sacramento Co., 189 Cal. 7, 207 Pac. 507 (1922); Estate of Donellan, 164 Cal. 14, 127 Pac. 166 (1912)

${ }^{8}$ Actually, because of the inherent nature of the inquiry, the duty is primarily the determination of a negative-what is not protectible and consequently not property. This is be- cause all hiterary works consist of a series of abstractions approaching concreteness. Nichols 
It is submitted that this principle is inherent in the California decisions, though possibly somewhat confused by the semantic difficulties that invariably, and perhaps inevitably, plague almost all the cases in this field. Golding v. RKO Pictures, Inc. ${ }^{9}$ apparently recognized that the existence of protectible property rights presented an issue of law, though the decision was confusing because of the inference that the existence of such right depended only on whether or not the material had been reduced to concrete form..$^{10}$ The Golding opinion stated ${ }^{11}$ (as pointed out in Weitzenkorn v. Lesser $\left.{ }^{12}\right)$ :

It is, however, only the product of the writer's creative mind which is protectible ... the plaintiff inust establish as the subject of the cause of action a right in the nature of property which is capable of ownership. ... It is essential ... to first dissect the play to determine wherein, if at all, plaintiffs have any protectible property right.

The Weitzenkorn decision not only dispelled by necessary inference the contention that concreteness of form was the sole issue of law; it went much further. It held generally that "The idea alone, the bare, undeveloped story situation or theme is not protectible" under the amended provisions of Section 980 of the Civil Code; and held specifically, that the so-called "basic dramatic core" of plaintiff's work in that case (and of plaintiff's work in the Golding case) would not be protected under Section 980 as amended. It further declared that the basic characters and locale of the Weitzenkorn story were not the subject of ownership. And in Burtis v. Universal Pictures Corporation ${ }^{13}$ the court directly determined that Burtis' claim to a protectible property interest in his characters was "not included within the monopoly of copyright." Both decisions reiterate and exemplify the necessity of the application by the court of the mechanics of dissection to determine what is and what is not literary property, in accordance with the Golding opmion.

v. Universal Pictures, 45 F.2d 119 (2d Cir. 1930). "Property" thus arises out of and is based upon nonproperty. The important function of the court therefore is to determine at what point "property" conumences to exist.

935 Cal.2d 690, 221 P.2d 95 (1949).

10 "Certainly, if the only product of the writer's creative mind is not something which the law recognizes as protectible, that is, ideas not reduced to concrete form, O'Brien v. RKO Radio Pictures, 68 F. Supp. 13, 14 (S.D.N.Y.1946), no right of action for infringeinent of literary property will lie even if the idea assertedly infringed is original and the result of his independent lahor." 35 Cal.2d 690, 695, 221 P.2d 95, 97 (1949). (italics added).

Treating the italicized words not as a limitation, but merely as an example, the statement is a holding that protectibility presents an issue of law. The Weitzenkorn case seems to make it clear that such words were not intended as any limitation.

1135 Cal.2d 690, 695, 221 P.2d 95, 97 (1949).

1240 Cal.2d 778, 256 P.2d 947 (1953).

1840 Cal.2d 823, 256 P.2d 933 (1953). 
The California cases in their inference that protectibility ("property") is a question of law for the determination of the judge are in accord with the inferences from other jurisdictions and with text writers. There appears to have been almost no direct case discussion of the question. ${ }^{14}$ Nevertheless, Warner, in his work "Radio and Television Rights," says "Protectibility on the other hand tenders a preliminary question of law." And many courts have determined as a matter of law that certain material admittedly authored by plaintiff does not constitute protectible property because it does not display imaginative creativeness beyond the bounds of the conimon property. ${ }^{16}$

As soon therefore as the trial court is presented with the issue of the scope of plaintiff's claimed property in his work, whether on demurrer or motions to the pleadings as contenplated by Code of Civil Procedure Section $426(3)$ or at the trial, it is the court's duty to determine and mark for itself initially, and for possible ultimate advice to the jury, the specific limits of plaintiff's protectible property interest.

This is, of course, a most difficult task because the field is one of abstractions. As Justice Story stated in Folsom v. Marsh: ${ }^{17}$

Patents and copyrights approach, nearer than any other class of cases belonging to forensic discussions, to what may be called the metaphysics of the law, where the distinctions are, or at least may be, very subtile and refined, and, sometimes, almost evanescent.

Nevertheless, we know now since Weitzenkorn and its two companion

14 In Arnstein v. Porter, 154 F.2d 464 (2d Cir. 1946), a musical plagiarism case, Judge Frank declared that "illicit appropriation" was a question of fact for the jury. Although his opinion is not clear, it seems that he is referring to the issue of similarity, not protectibility. Judge Frank's strict views as to the necessity for presenting almost all matters of similarity to a jury met with a vigorous dissent from Judge Clark in the Arnstein case, and have been otherwise the subject of adverse comment. Asbill and Snell, Summary Judgment, 51 MICH. I. REv. 1143 (1953). Cf. Note, 38 CAIIF. I. REv. 332 (1950). They do not accord with the treatment given by most courts to the issue. See discussion of "The Issue of Similarity," infra.

15 This work, the newest in the field, evidences a prodigious amount of scholarly effort; it contains a superb collection of authorities and much reasoned comment. It is thus most unfortunate that a very substantial part of the work is constructed upon legal foundations now destroyed. The author has relied to an unusual degree upon the decisions in the Stanley, Golding and Kovacs cases, without apparently recognizing that these cases were decided before the important 1947 amendment to CAL. Crv. CoDE $\$ 980$; and upon the decisions of the District Courts of Appeal in Weilzenkorn, Kurlan, and Burtis, which decisions have been completely overturned by the Supreme Court's opinions in those cases, after hearing granted. Mr. Warner spends many pages reviewing these now generally inapplicable decisions, and their citations in his work easily run into the hundreds. It is all the more surprising since his Preface is dated July 15, 1953, whereas hearings were granted by the Supreme Court in Weitzenkorn and Kurlan in 1951, and the Weitzenkorn, Kurlan, and Burtis cases were decided by the Supreme Court on April 29, 1953.

16 See Appendix.

179 Fed. Cas. 342 , No. 4,901, at 344 (C.C. Mass. 1841). 
cases, Kurlan v. Columbia Broadcasting System, Inc. and Burtis v. Universal Pictures Corporation, ${ }^{18}$ that property presently exists only in the "originality of form and manner of expression, the development of characterizations and sequence of events"; that it no longer exists in "ideas" or "dramatic cores" or in the "bare, undeveloped story situation or theme." We know also that "California now accepts the traditional theory of protectible property under common law copyright," and we can look to the many cases in the Federal courts and those of sister states delineating the scope of protectible property with the general assurance that California is in harmony with such decisions.

Regardless of the variations of terminology occasioned by the limitations of the English language in treating with such evanescent abstractions, the cases generally exhibit a surprising umfornity of approach and conception. The courts wholeheartedly recognize that ideas, new or old, when once disclosed must be kept "free as air" for all to use. ${ }^{19}$ They recognize further that the vast accumulation of human experience, the character of man and his world in all its varying phases, and the relationships of each to the other and to other inen and other things, not only in the general but the specific, are not and cannot become the "property" of anyone regardless of how they are expressed. These things are the universal heritage, the public commons, from which all may freely draw sustenance and which all may use as seems most satisfactory to them. ${ }^{20}$

For that reason the law limits the claim of private protectible property to the adornments and embellishments, great or small, that the individual gives to his share of the common property; the individual's "form and manner of expression" or his "development" or "treatment." It denies such claim to the relationships ("situations"21 or "concepts"22); or to the results human experience shows ordinarily will or may occur from such

1840 Cal.2d 799, 256 P.2d 962 (1953); 40 Cal.2d 823, 256 P.2d 933 (1953).

19 Weitzenkorn v. Lesser, 40 Cal.2d 778, 256 P.2d 947 (1953); Fendler v. Morosco, 253 N.Y. 281, 171 N.E. 56 (1930); see Appendix.

20 AMIDUR, Copyright LAw 75 (1936); Eichel v. Marcin, 241 Fed. 404 (S.D.N.Y. 1913); Sheldon v. Metro-Goldwyn Pictures Corp., 7 F. Supp. 837, 843 (S.D.N.Y. 1934) ; Nichols v. Universal Pictures Corp., 45 F.2d 119 (2d Cir. 1930); Maxwell v. Goodwin, 93 Fed. 665 (C.C. IIl. 1899) ; Cain v. Universal Pictures, Inc., 47 F. Supp. 1013 (S.D. Cal. 1942) ; Schwarz v. Universal Pictures, Inc., 85 F. Supp. 270 (S.D. Cal. 1945) ; London v. Biograph Co., 231 Fed. 696 (2d Cir. 1916); Roe-Lawton v. Roach Studios, 18 F.2d 126 (S.D. Cal. 1927) ; Wiren v. Shubert Theatre Corp., 5 F.Supp. 358 (S.D.N.Y. 1933) ; Bagge v. Miller, MacGmuvRAY, CopyrigrT CASES 1917-23, 179; see Appendix. Dr. Samuel Johnson wrote an essay on this subject which is quoted at some length in Lewys v. O'Neill, 49 F.2d 603 (S.D.N.Y. 1931).

21 Wiren v. Shubert Theatre Corp., 5 F. Supp. 358, 363 (S.D.N.Y. 1933), aff'd, 70 F.2d 1023 (1934); Echevarria v. Warner Bros. Pictures, Inc., 12 F.Supp. 632 (S.D. Cal. 1935) ; Hewitt v. Coward, 180 Misc. 1065, 41 N.Y.S.2d 498 (Sup. Ct. 1943).

22 Eichel v. Marcin, 241 Fed. 404 (S.D. N.X. 1913). 
relationships ("dramatic cores,"23 "themes,"24 "skeleton plots," "s5 "scenes a'faire,"26 "necessary or routine incidents" 27 ). It denies such claim to background, ${ }^{28}$ locale, ${ }^{29}$ or historic facts ${ }^{30}$ either in or out of juxtaposition with other unprotectible elements. And since man is man regardless of the particular experiences to which he is subjected, it should and probably does deny any property right in any "character" apart from any particular series of events in which he acts. ${ }^{31}$

These elements niay be encompassed by the general word "ideas," for lack of a more accurate tern. They are denied protectibility because of their universality; they are the raw materials with which creative imaginations must work, and under no circumstances can they in and of themselves become the private property of any individual.

There are many differences in terminology ${ }^{32}$ and each case presents

23 Weitzenkorn v. Lesser, 40 Cal.2d 778, 256 P.2d 947 (1953).

24 Solomon v. RKO, 44 F. Supp. 780 (S.D. N.X. 1942); Ornstein v. Paramount Productions, 9 F. Supp. 896 (S.D.N.Y. 1935); Gropper v. Warner Bros. Pictures, 38 F. Supp. 329 (S.D.N.Y. 1941).

25 Shipman v. RKO Radio Pictures, Inc., 100 F.2d 533 (2d Cir. 1938); Gropper v. Warner Bros. Pictures, Inc., 38 F. Supp. 329 (S.D. N.Y. 1941) ; Dymow v. Bolton, 11 F.2d 690 (2d Cir. 1926); Hewitt v. Coward, 180 Misc. 1065, 41 N.Y.S.2d 498 (Sup. Ct. 1943).

26 Cain v. Universal Pictures Corp., 47 F. Supp. 1013 (S.D. Cal. 1942).

27 O'Rourke v. RKO Pictures, 44 F. Supp. 480 (D. Mass. 1942); Rush v. Oursler, 39 F.2d 468 (S.D.N.Y. 1930); Caruthers v. RKO Radio Pictures, Inc., 20 F. Supp. 906 (S.D. N.Y. 1937).

28 Fendler v. Morosco, 253 N.Y. 281, 171 N.E. 56 (1930); Nichols v. Universal Pictures, 45 F.2d 119 (2d Cir. 1930).

29 Caruthers v. RKO Radio Pictures, 20 F. Supp. 906 (S.D.N.Y. 1937); Echevarria v. Warner Bros. Pictures, 12 F. Supp. 632 (S.D. Cal. 1935); Fendler v. Morosco, 253 N.Y. 281, 171 N.E. 56 (1930).

30 Caruthers v. RKO Radio Pictures, supra note 29; Echevarria v. Warner Bros. Pictures, supre note 29; Funkhouser v. Loew's Inc., 108 F. Supp. 476 (D.Mo. 1952); Maddux v. Grey, 43 F.2d 441 (S.D. Cal. 1930).

81 Burtis v. Universal Pictures, 40 Cal.2d 823, 256 P.2d 933 (1953); Kelley v. Cinema Houses, Ltd., MacGitrvrax, Copyriget Cases 1932-33 362; Lewys v. O'Neill, 49 F.2d 603, 612 (S.D.N.Y. 1931) ; Lone Ranger, Inc. v. Cox, 39 F. Supp. 487, 490 (W.D.S.C. 1941), reversed on other grounds, 124 F.2d 650 (4th Cir. 1942); see Nichols v. Universal Pictures, 45 F.2d 119, 121 (2d Cir, 1930); Detective Comics, Inc. v. Bruns Publication, Inc, 111 F.2d 432, 434 (2d Cir. 1940) ; cf. Yankwich, Originality in the Law of Intellectual Property, 11 F.R.D. 457, 465 (1951). The performance of an actor (his voice, posture, movements and the "stage business" accompanying them which actually creates a character) is not covered by copyright. Chappell \& Co. v. Fields, 210 Fed. 864, 865 (2d Cir. 1914); Bloom \& Hamlin v. Nixon, 125 Fed. 977 (C.C.E.D. Pa. 1903); Savage v. Hoffmann, 159 Fed. 584, 585 (C.C.S.D. N.Y. 1908). Of course, if the name of the character or his identifiable attributes has acquired a secondary meaning, any deceptive use might permit a cause of action in unfair competition. See Chaplin v. Amador, 93 Cal. App. 358, 269 Pac. 544 (1928).

32 The use of "plot" is a good example. In some cases it is held that a "plot" may constitute protectible property, Nichols v. Universal Pictures Corp., 45 F.2d 119 (2d Cir. 1930); Dam v. Kirk La Shelle Co., 175 Fed. 902 (2d Cir. 1910) ; in others, "plots" are said to be nonprotectible, Gropper v. Warner Bros. Pictures, 38 F. Supp. 329 (S.D.N.Y.1941); Dymow v. Bolton, 11 F.2d 690 (2d Cir. 1926); Eichel v. Marcin, 241 Fed. 404 (S.D.N.Y.1913). 
individual facts. Nevertheless, a study of the opinions leads one to the clear conclusion that in general the courts appreciate the vital importance of preventing this public commons ${ }^{33}$ from being fenced in by any private individual, and have recognized its scope and extent. While, therefore, the task facing a court in determining the specific extent of plaintiff's property right in any particular work is not easy, it is unuch more difficult in the definition than in the application. ${ }^{34}$ At any rate, it is submitted that it is clearly the court's task. As was said by Judge Learned Hand in Nichols v. Universal Pictures Corp.: ${ }^{35}$

We have to decide how much, and while we are as aware as any one that the line, wherever it is drawn, will seem arbitrary, that is no excuse for not drawing it; it is a question such as courts must answer in nearly all cases.

The necessity that the court determine with clarity the specific elements in plaintiff's work which may be entitled to legal protectibility and those which may not is not only occasioned by the possibility that this issue may be presented to the judge on demurrer or through motion for nonsuit or directed verdict. A determination that certain specific elements are not the subject of property affects any possible jury question in two vitally iniportant ways: (1) Those elements are unprotectible regardless of whether the jury believes that they were conceived by plaintiff independently of any other source, and (2) those elements are free to be used by

Examination will show, however, that in the second group the word is used as synonymous with "theme" or the generalized story line; in the first group the word is given its dictionary definition of "the plan or main story of a hterary composition, comprising a complication, or causally connected series, of motivated incidents which are gradually unfolded, sometimes hy unexpected means." WEBSTER, NEW INT'x DictIONARX (2d ed.). The representations or expression of such a "plot" can be property. See coucurring opinion in Shipman v. RKO Radio Pictures, 100 F.2d 533 (2d Cir. 1938).

33 In the above discussion I have used the words "public commons" to describe these elements which can under no circumstances constitute private property, and avoided the more usual "public domain," because the latter phrase leads to confusion. "Public domain" of course includes these elements, but it includes also any pre-existing published works which were not mitially protected by statutory copyrigut, or on which such protection has expired; in fact this is its usual techmical meaning. Such works are freely open for use by either plaintiff or defendant, but it is not the law that plaintiff's claim of a property interest is mevitably defeated by the prior existence of similar material in works in the "public domain." See discussion infre.

34 A striking instance of the difficulties of definition is the oft repeated statement that while there can be no hterary property im ideas there may be such in a combination of ideas. Fendler v. Morosco, 253 N.Y. 281, 285, 171 N.E. 56, 58 (1930). The statement gets one nowhere. Take the single idea "boy meets girl" (sed quaere: is this one, or a combination of three, (1) boy, (2) girl, (3) act of meeting?). On this idea the following different combimations are immediately apparent: (1) Boy meets girl; they love; they marry; (2) boy meets girl; they don't love; they marry; (3) boy meets girl; they love; they don't marry; (4) boy meets girl; they don't love; they don't marry. Obviously, although these are all "combmatious," none of them constitutes protectible property.

3545 F.2d 119, 122 (2d Cir. 1930). 
the defendant regardless of the fact that he took them from plaintiff's work. ${ }^{36}$

Comment has already been made on the semantic difficulties presented in literary property problems. Nowhere are these more apparent than when we come face to face with the ambiguous word "originality." It is often said that "originality" is an essential ingredient of plaintiff's work. "Originality" has two distinct meanings, each having its own distinct and different bearing upon the issue of the ownership of literary property. In its broad sense, a work possesses "originality" to the extent that it departs from the trite, expected, or commonplace. In its narrow sense, the word connotes merely the individuality of its origin - that the particular thing was the independent product of its claimed author. The first is an objective meaning; the second, subjective. ${ }^{37}$

The objective, broad concept of originality or lack of originality is a factor in the legal determination of whether particular material or elements are capable of constituting literary property. To the extent that plaintiff has done no more than duplicate a part of the "public commons" -has presented a commonplace situation leading to stock incidents and peopled with stock characters - he has not created any "property," and that regardless of any claim he may have that the work was the product of his own mind. These elements, either separately or in combination, lack "originality" in the broad sense, the sense believed to have been used by Judge Yankwich in his illuminating essay, "Originality in the Law of Intellectual Property." ${ }^{38}$ It is because of their necessary inclusion in the common stock of human experiences, relationships and characteristics that the courts have held as a matter of law that there is no protectible property in hackneyed incidents, especially those following as a matter of course from the basic situation, or in "stock" characters. Nowhere is this principle better expounded than by Judge Learned Hand in his magnificent opinion in the Nichols case. ${ }^{39}$

Since it is the function of the court to draw the line between property and nonproperty im plaintiff's work and thus to determine the extent of the public commons, it will give regard to "originality" in this sense as a part of its legal determmation. ${ }^{40}$ However, "originality" in the narrow

36 Sheldon v. Metro-Goldwyn-Mayer, 81 F.2d 49, 54 (2d Cir. 1936); Dellar v. Samuel Goldwyn, Inc., 150 F.2d 612 (2d Cir. 1945); Nichols v. Universal Pictures Corp., 45 F.2d 119 (2d Cir. 1930); Dymow v. Bolton, 11 F.2d 690 (2d Cir. 1926); Ornstein v. Paramount Productions, Iric., 9 F. Supp. 896 (S.D. N.Y. 1935) ; Rush v. Oursler, 39 F.2d 468 (S.D. N.Y. 1930).

37 Cf. Frank, J. in Alfred Bell \& Co. v. Catalda Fine Arts, 191 F.2d 99 (2d Cir. 1951).

3811 F.R.D. 457 (1951).

39 Nichols v. Universal Pictures, 45 F.2d 119 (2d Cir. 1930).

40 To assist the judge in this determination, and in delineating the bounds of the public common, it would be perfectly proper to call his attention to standard antecedent works of hiterature. The purpose in such procedure is not to prove, through doctrines of judicial notice, that plaintiff copied from such works, or even that plaintiff's "expression or treatment" has 
sense-that of origin or authorship-is of vital importance in other issues in a literary property case. For plaintiff to recover he must show that such property as may appear in his alleged work is his property-is an independent creation, not copied or taken, consciously or unconsciously, from some other source-and is thus "original" in the subjective sense. ${ }^{41}$ It is submitted that this presents a question of fact.

Because of the ambiguity in the terms "original" and "originality," it is to be regretted that they have been used in this field, although it is probably too late for any correction. Such use inevitably leads to confusion which has been emphasized by historic developments in the law.

Some of the early cases under the Federal Copyright Law, especially those dealing with pictorial or graphic material, permitted juries to speculate as to whether such material constituted "works of art" - to weigh the artistic merit or demerit of drawings or photographs. ${ }^{42}$ This view was rejected by the United States Supreme Court in Bleistein v. Donaldson Lithographing $\mathrm{Co}^{43}$ In that case the lower court had held that certain lithographed circus posters depicting actual performers did not possess sufficient artistic merit to permit of copyrightability, and therefore refused to submit the case to a jury. The Supreme Court, per Justice Holmes, held that the posters were copyrightable if created by plaimtiff, regardless of conflicting views as to their artistic merit. ${ }^{44}$

been anticipated. The court in Weitzenkorn held that judicial notice cannot be so far extended; it is submitted that the holding is proper. Rather, the purpose is to show the extent to which plaintiff's work is based on universalities, and contains those matters which age and usage have made part of the common heritage and thus not capable of private ownership. These matters are not demied protectibility because the great (or small) minds of literature, ancient or modern, wrote about them; in fact, it may be assumed that in most instances they wrote about them precisely because they were old and common then as well as now-because they possessed the umiversality of experience and humaneness-and were embodied in songs and stories and legends, as well as in life itself, long before Homer or Shakespeare or Balzac or Edgar Rice Burroughs were born. Cf. London v. Biograph Co., 231 Fed. 696 (2d Cir. 1916). The judge should inform himself, or be informed, of the fields which have been plowed and replowed in the past, in order to determine where to set the fences dividing the public commons from the creative individual possession of the modern writer. See Appendix.

41 "One requisite to copyrightability is that the work be original in the sense of being the creative product of the author's own effort." AMrdur, Copyrughr LAw 69 (1936). See National Tel. News Co. v. Western Umion Tel. Co., 119 Fed. 294, 297 (7th Cir. 1902).

42 Bolles v. Outing Co., 77 Fed. 966 (2d Cir. 1897); Hegeman v. Springer, 110 Fed. 374 (2d Cir. 1901).

43188 U.S. 239 (1903).

44 The Bleistein case has been cited for the proposition "that originality [in the broad or objective sense] is a question of fact for the jury." Dezendorf v. Twentieth Century-Fox Film Corp., 99 F.2d 850 (9th Cir. 1938); see text at note 46 infra. The case does not so hold. It is authority rather for the proposition that given something which the law considers property (as these posters if conceived and drawn by plaintiff surely were) the law is not concerned with their artistry in the cultural sense. The Supreme Court sent the case back because there were other jury issues, including that of plaintiff's "authorship," although as to that issue Justice Holmes said: "It would be pushing defendant's rights to the verge, even beyond, to leave the question of originality [narrow sense] to the jury on the evidence in this case." See Umbreit, A Consideration of Copyright, 87 U. OF PA. L. REv. 932 (1939). 
As a necessary corollary to this holding, the Bleistein case declared that such posters, being protected by copyright, could be the subject of infringement and that this was so even though their subject matter was not protectible. "Others are free to copy the original. They are not free to copy the copy." ${ }^{45}$ This principle-that with respect to those elements in his work which are capable of protectibility as "property" plaintiff need only prove his authorship and cannot be deprived of his rights therein merely because someone else anticipated their creation-has become settled law. ${ }^{46}$ As Judge Hand said in Sheldon v. MGM Pictures Corporation: ${ }^{47}$

It is plain beyond peradventure that anticipation as such cannot invalidate a copyright. Borrowed the work must indeed not be, for a plagiarist is not himself pro tanto an "author"; but if by some magic a man who had never known it were to compose anew Keats' Ode on a Grecian Urn, he would be an "author", and if he copyrighted it, others might not copy that poein, though they might of course copy Keats.

Therefore, "originality" im the narrow sense - authorship—is all plaintiff must prove to show his ownership of protectible material once the existence of such protectible material has been established as a matter of law. Nevertheless, it must always be remembered that protectibility in law must be established first (including "originality" in the broad sense) and that such protectibility does not result from plaintiff's independent duplication of matter in the public commons. This is emphasized by the very courts which have best developed the principle that property need not be novel to be protectible. ${ }^{48}$

Much of the confusion in the use of this word stems from the decision of the Ninth Circuit Court of Appeals in Dezendorf v. Twentieth CenturyFox Film Corporation. ${ }^{49}$ In that case the parties had attached the two conflicting works to the pleadings, and defendant's motion to dismiss had been granted by the lower court on a comparison of the works. In so doing, that court accepted a procedure approved by other Federal courts. ${ }^{50}$ The

45188 U.S. 239, 249 (1903).

46 Fred Fisher, Inc. v. Dillingham, 298 Fed. 145 (S.D.N.Y. 1924); Gingg v. Twentieth Century-Fox Film Corp., 56 F. Supp. 701, 708 (S.D. Cal. 1944); Seltzer v. Sunbrock, 22 F. Supp. 621,627 (D.C. Cal. 1938) ; Ricker v. General Electric Co., 162 F.2d 141 (2d Cir. 1947); Drone, Copyright 205 (1879); AMdoUR, Copyright LAw 69 (1936). There are some statements that material must be "novel" to be protectible. Harold Lloyd Corp. v. Witwer, 65 F.2d 1, 23 (9th Cir. 1933); Simonton v. Gordon, 297 Fed. 625, 626 (S.D.N.Y. 1924); see Stevenson v. Harris, 238 Fed. 432 (S.D. N.Y. 1917). From their context, however, it is believed that this merely means they must have "originality" in the broad sense-must depart from the bounds of the public common.

4 ir 81 F.2d 49, 54 (2d Cir. 1936).

48 Ibid.; cases cited notes 36,45 supra; Yankwich, supra note 38 .

4099 F.2d 850 (9th Cir. 1938).

50 Lowenfels v. Nathan, 2 F. Supp. 73 (S.D.N.Y. 1932); Shipman v. RKO Radio Pictures, 20 F. Supp. 249 (S.D.N.Y. 1937), aff'd, 100 F.2d 533 (2d Cir. 1938). The procedure is 
Court of Appeals reversed on the ground that "We are confronted with a 'nice question of originality' which is one of fact, not of law; one ... which must be established by proof." 51

If this case uses "originality" in the broad sense as meaning protectibility, it is submitted that it is erroneous and unsupported by the authorities it cites. The "nice question of originality" referred to in the cases from which it borrows that phrase was clearly the issue of authorship, as appears from a reading of those decisions. ${ }^{52}$ Authorship was admitted by the motion to dismiss. The court relies otherwise on the Bleistein case (already discussed), on the early case of Henderson $v$. Tompkins, ${ }^{53}$ and on several patent cases. ${ }^{54}$ In patent cases the issue is one of novelty or lack of precedent. The distinction between patents and copyriglits $\mathrm{m}$ this connection is well-recognized. ${ }^{55}$

The confusion created by the ambiguity in the term "originality" and its erroneous use in the Dezendorf case ${ }^{56}$ has carried over to the California decisions. In Stanley, Justice Carter makes the statenuent that the "question of originality of plaintiff's program is not one of law to be determined by the court, but is one of fact for the jury's determination," ${ }^{57}$ citing Dez-

the same as now prescribed in CAI. CODE CIV. PrOC. $\$ 426(3)$ and upheld in Weitzenkorn v. Lesser, 40 Cal.2d 778, 256 P.2d 947 (1953), and Kurlan v. Columbia Broadcasting System, 40 Cal.2d 799, 256 P.2d 962 (1953). But see MacDonald v. DuMaurier, 144 F.2d 696 (2d Cir. 1944); Arnstein v. Porter, 154 F.2d 464 (2d Cir. 1946).

51 Dezendorf v. Twentieth Century-Fox Film Corp., 99 F.2d 850, 851 (9th Cir. 1938). The court distinguished the Lowenfels and Shipman cases, supra note 50, on the grounds that they were copyright cases involving "fair use." The distinction is not valid. The issue of protectibility exists in the same form in common law cases as in copyright cases. Fendler v. Morosco, 253 N.Y. 281, 171 N.E. 56 (1930); Schwarz v. Unversal Pictures Co., 85 F. Supp. 270 (S.D. Cal. 1945) ; Caruthers v. RKO Radio Pictures, 20 F. Supp. 906 (S.D.N.Y. 1937) ; Hewitt v. Coward, 180 Misc. 1065, 41 N.Y.S.2d 498 (Sup.Ct. 1943) ; Heywood v. Jericho Co., 193 Misc. 905, 85 N.Y.S.2d 464 (Sup. Ct. 1948) ; Maxwell v. Goodwin, 93 Fed. 665 (C.C. Ill. 1899); cf. Golding v. RKO Radio Pictures, 35 Cal.2d 690, 221 P.2d 95 (1950); Weitzenkorn v. Lesser, 40 Cal.2d 778, 256 P.2d 947 (1953). "Fair use" presents a different question. See note 1 supra.

52 Lowenfels v. Nathan, 2 F. Supp. 73 (S.D. N.Y. 1932); Shipman v. RKO Radio Pictures, 20 F. Supp. 249 (S.D.N.Y.1937).

5360 Fed. 758 (C.C. Mass. 1894).

54 New York Belting Co. v. New Jersey Rubber Co., 137 U.S. 445 (1890); American Fibre-Chamois Co. v. Buckskin Fibre Co., 72 Fed. 508 (6th Cir. 1896); Jackes-Evans Mfg. v. Hemp \& Co., 140 Fed. 254 (8th Cir. 1905). Henderson v. Tompkins, 60 Fed. 758 (C.C. Mass. 1894) discussed "originahty" in both senses. It held that an allegation of authorship was binding on demurrer and foreshadowed the Bleistein case by indicating that hiterary merit, except in the very lowest degree, was not essential for copyrightability.

55 Fred Fisher, Inc. v. Dillingham, 298 Fed. 145 (2d Cir. 1924); Bart, Copyrigri 326 (1944).

56 It is interesting to note that on the return of the Dezendorf case to the lower court, that court found that although some similarities existed they were in nonprotectible material and gave judgment for defendant just as it had on the original motion to dismiss. Dezendorf $v$. Twentieth Century-Fox, 32 F. Supp. 359 (S.D. Cal. 1940). On appeal the Circuit Court affirmed per curriam, 118 F.2d 561 (9th Cir. 1941). Compare MacDonald v. Du Maurier, 144 F.2d 696 (2d Cir. 1944), with MacDonald v. Du Maurier, 75 F. Supp. 655 (S.D.N.Y. 1948) where the same result occurred.

6735 Cal.2d 653, 665, 221 P.2d 73, 80 (1950). 
endorf, Yadkoe v. Fields, and the New York Belting case. ${ }^{58}$ Actually the issue in Stanley was "novelty" (lack of precedent) rather than "originality" in either of the senses in which we have used it, but the context of the opinion gives rise to the inference that Justice Carter was dealing with protectibility in general. On the other hand, in Golding the court uses the word primarily in the narrow sense of authorship:

The fact that the plan or theme of the plaintiff's story is similar to the plots of prior stories does not defeat the claim of originality within the meaning of that word for copyright purposes. "It is not essential that any production to be original or new within the meaning of the law of copyright shall be different from another. ... The true test of originality is whether the production is the result of independent labor or of copying." 59

However, when subsequently it refers to the "preliminary issue of originality or of plaintiff's protectible property interest," it is not clear whether the word is being used in the subjective or objective sense.

In Weitzenkorn, the court seems to use the word in both senses without clear distinction. It holds that, on demurrer, plaintiff's work possesses "originality" because (1) common and general knowledge does not extend to establish "lack of originality" (objective definition) in treatment and expression, and (2) a court may not find by judicial notice that plaintiff copied from previous particular works (subjective definition). ${ }^{60}$ The use of the word in other parts of the Weitzenkorn opinion presents additional difficulties. Thus, although the court repeats the Stanley statement that "originality is a question of fact for the jury," it does not specifically reaffirm it. Instead it states that "in the first instance the question of originality or novelty is one of law." It would seem that this use of the term "originality" cannot refer to the narrow sense, for it is difficult to see how an allegation of independent authorship could be disregarded on demurrer..$^{01}$

Finally the court says in Weitzenkorn that the "question whether she has a protectible property interest depends upon the originality of form and manner of expression, the development of characterizations and sequence of events." This is certainly correct in the sense that plaintiff must show independent authorship in fact, and also in the sense that the law will

58 New York Belting Co. v. N. J. Rubber Co., 137 U.S. 445 (1890). Yadkoe v. Fields, 66 Cal. App.2d 150, 151 P.2d 906 (1944), an "idea" case tried before the amendment to Car. CIv. CoDE $\$ 980$, involved novelty. It contains the statement: "The question of originality, however, is one of fact for the jury," citing Dezendorf as authority.

5935 Cal.2d 690, 697, 221 P.2d 95, 99 (1950).

6040 Cal.2d 778, 787, 256 P.2d 947, 954 (1953).

61 See Lillard v. Sun Printing Ass'n, 87 Fed. 213 (C.C.S.D. N.Y. 1898); Henderson v. Tompkins, 60 Fed. 758 (C.C. Mass. 1894). However, an allegation of novelty could be determined on demurrer. General knowledge is often sufficient to establish lack of novelty. Kurlan v. Columbia Broadcasting System, 40 Cal.2d 799, 808, 256 P.2d 962, 968 (1953), and cases cited note 105 infra. 
not protect any person in his claim to ownership of matters which by reason of their nature or age have become part of the public commons. But does it go further and require that plaintiff's property right be limited to that which no other has anticipated, thus adopting the dictum of Harold Lloyd Corporation v. Witwer ${ }^{62}$ that the material must be new and novel?

If this be true it adds a requirement of California law not consonant with general law. ${ }^{33}$ The rule that once plaintiff's property rights have been determined as a matter of law they cannot be destroyed merely by a showing that they have been anticipated in point of time by some other creator of property rights was recognized in Golding, and it does not seem that the court in Weitzenkorn intended to retreat therefrom. In spite of the confusion occasioned by the use of this ambiguous term, it is submitted that the true rule deducible from Weitzenkorn and its compamion cases is that "originality" in its broad sense as constituting a determiming factor in establishing whether the author has created something beyond the bounds of the "public commons" is of relevance for the court; "originality" in its narrow sense, as relating to plaintiff's independent authorship of the material so determined to be beyond such bounds, is a matter for the jury. Such being the case, plaintiff has no protectible interest in that which is not property, even though he "originated" it. On the other hand, plaintiff will be protected in that which is property and created by him, even though others may have also (and independently) created the same thing.

It is apparent, therefore, that it is of great importance for the judge not only to determine with clarity what in plaintiff's work is not entitled to legal protection, but when necessary to impart that determination to the jury with equal clarity. This should not be done by legal definition, but by direction as to specific elements. Thus, if Miss Weitzenkorn should ever again claim her work "Tarzan in the Land of Eternal Youth" to be plagiarized by some new story, having sufficient similarities in form and manner of expression, treatment, development and sequence of events to warrant jury submission, the jury should be charged specifically that the basic characters of "Tarzan," "Jane" and "Cheta," the African locale, and the situation or "dramatic core" created by the combination of these characters with others in that locale and in connection with the search for a fountain of eternal youth, are not the property of plaintiff and may be freely used by defendants, even though these "ideas" were suggested to defendant by a reading of plaintiff's work. It would not be sufficient, it is submitted, merely to charge in such a case, in general terms, that "the idea alone, the bare, undeveloped story situation or theme is not protectible." That would be

6265 F.2d 1, 22, 23 (9th Cir. 1933).

03 Note 46 supra. 
to permit the jury to make its own determination as to what is the idea, situation or theme and thus determine the peculiarly legal issue of property on uncontradicted facts.

In actions for malicious prosecution defendant may avoid liability by showing the existence of probable cause for such prosecution. Whether or not the facts constitute such probable cause is a question of law for the court, just as is the question of what matters in a literary work are demed protectibility and thus do not arise to the dignity of property rights. It is well-settled that in any malicious prosecution case it is error for the court to give to the jury a definition of probable cause and instruct it to find for or against the defendant accordingly as it may determine that the facts are within or without that definition.

Such an instruction is only to leave to them in another form the function of determining whether there was probable cause. The court cannot divest itself of its duty to determine this question, however complicated or numerous may be the facts. It must instruct the jury upon this subject in the concrete, and not in the abstract, and must not leave to that body the office of determining the question, but must itself determine it, and direct the jury to find its verdict in accordance with such determination. ${ }^{64}$

Here, where the problem of definition involves as it does the use of abstract terms to describe abstractions, there are even more cogent reasons for specification and exactitude in instructions. In making its examination of the plaintiff's work, the court must itself determine what is unprotectible therein in the concrete-must apply the rules of law determining protectibility to the particular work before it. It is submitted that being itself required to make such determination, it must be equally concrete in its instructions in those cases where it becomes necessary to advise the jury as to what in law is not property in plaintiff's work. ${ }^{65}$

64 Ball v. Rawles, 93 Cal. 222, 28 Pac. 937 (1892) ; accord, Aitken v. White, 93 Cal. App. 2d 134, 141, 208 P.2d 788, 791 (1949), citing other cases; $c f$. as to the rule in libel and slander, Maher v. Devlin, 203 Cal. 270, 263 Pac. 812 (1928); Carpenter v. Ashley, 148 Cal. 422, 83 Pac. 444 (1906) ; Ballard v. Krug, 111 Cal. App. 555, 295 Pac. 871 (1931).

05 In Maxwell v. Goodwin, 93 Fed. 665, 666 (C.C.N.D. Ill. 1899) the jury was instructed "in reference to alleged resemblances between the two plays in general feature-such as scencs laid in Washington, and relating to congressional legislation, honest and dishonest senators or congressmen beset by temptation at the hands of a sugar trust, love scenes complicating the plot, secretaries, Negro servants, dudes, and other accessories of the modern drama-that they were, with the general theme or story showing the triumph of an honest legislator over corrupt influences, common subjects, for imagination, at least, in which the plaintiff possessed no right of literary property; that, unless identity was found in the matter and expression showing that one was copied from the other substantially and in material parts, although not in the exact language or form, there was no piracy, and the defendant was not liable in this action." Concerning this instruction the court said, "There can, however, be no identity of the production, on which to establisil a right of action at common law, short of the test indicated in this instruction." Id. at 667. It is submitted that the case is an example of a proper type of instruction which should be directed, of course, to the particular work which is the subject of the action. 


\section{The Issue of Authorship}

As has been indicated, it is not only essential to plaintiff's claim for recovery that his alleged work contain elements of protectible property; these inust be his own and not the result of the conscious or unconscious use of other works. They must be "original" with the plaintiff in the subjective sense. The determination of this issue presents a question of fact.

Since plaintiff is entitled to claim ownership in any property he individually created, regardless of its anticipation (even exactly) by other writers, the question usually becomes one of his word as against circumstantial evidence consisting of available prior works of such similarity as to indicate they were consciously or unconsciously used by him. Regardless of the extent of such similarity, it is believed that the issue cannot be decided on demurrer because the fact of plaintiff's individual authorship, which must be alleged, must be accepted as true. ${ }^{66}$ If the similarity were sufficiently close, however, a court might properly grant a nonsuit or motion for a directed verdict on the ground that plaintiff's testimony was inherently improbable. ${ }^{67}$ It would seem, for example, to require something more than plaintiff's uncorroborated word to support a finding that he had individually created an "Ode on a Grecian Urn" in the identical form as written by Keats, without having consciously or unconsciously utilized Keats' work.

Nevertheless, in the ordinary case, it is for the jury to say whether the material which the court has declared to it to be capable of being "property" was independently created by plaintiff or derived consciously or unconsciously from available antecedent literary sources either in the public domain or covered by copyright.

\section{The Issue of Similarity}

It is almost a certainty that the issue of similarity must be faced in any plagiarism case. Unless plaintiff has done nothing more than slavishly copy some other work, practically every writing that arises to the dignity of a "composition in letters"-whether story, novel, play, scenario or scriptwill contain some elements capable of protectibility. If nothing more, plaintiff will have expressed old thoughts, ideas, incidents, developments and the like in his own arrangement of words and such particular arrangement

60 Henderson v. Tompkins, 60 Fed. 758 (C.C. Mass. 1894); Lillard v. Sun Printing Ass'n, 87 Fed. 213 (C.C.S.D.N.Y. 1898); $c f$. Wirin v. Shubert Theatre Corp., 5 F. Supp. 358 (S.D. N.Y. 1933).

67 Sanan v. Schoenborn, 47 Cal. App.2d 366, 117 P.2d 731 (1941); see Neilson v. Houle, 200 Cal. 726, 727-28, 254 Pac. 891-92 (1927); Tobola v. Wholey, 75 Cal. App.2d 351, 170 P.2d 952 (1946).

68 Holmes v. Hurst, 174 U.S. 82, 86 (1899) ; Eichel v. Marcin, 241 Fed. 404 (S.D.N.Y. 1913). 
would be protectible..$^{68}$ Thus, in all three of the recent California cases the Supreme Court found that protectible property of some nature existed. It will be the rare case indeed where the court may hold that as a matter of law plaintiff has no protectible property of any sort, and therefore cannot recover regardless of similarity or copying. ${ }^{69}$

Assuming some such protectible material, however, unless some substantial similarity exists between defendant's work and the protectible property in plaintiff's work, there can be no infringement of plaintiff's rights. This is undoubtedly a factual inquiry and was correctly recognized as such in both Golding and Weitzenkorn."

However, though the issue is factual in nature, it does not depend in any respect upon the determination of any evidentiary facts. As Weitzenkorn says, "The only evidence of similarity between the productions which can be presented is the productions themselves." The question is thus limited to the facts which appear or may properly be inferred from uncontradicted evidence. That presents an immediate issue of law for the court. The judge must determine whether the uncontradicted (and uncontradictable) evidence of the two works themselves is sufficient to warrant a finding of similarity between them as to plaintiff's protectible property. If it is not, there is no question of fact for the jury. This is the holding of the three companion cases of Weitzenkorn, Kurlan and Burtis, and it is supported by the great weight of other authorities. ${ }^{71}$

To make such determination, comparison must be made between the two works as to the protectible portion only of plaintiff's work. ${ }^{22}$ Thus, the vital importance of the court's careful determination as to what specific elements do or do not constitute property is again emphasized. As Justice Edmonds said in Golding: ${ }^{73}$

The property right must be fully analysed and closely defined because in the subsequent determination of the issue of copying, it is necessary to

69 But cf. Dorsey v. Old Surety Life Ins. Co., 98 F.2d 872 (10th Cir. 1938).

70 Accord, Encyclopaedia Britannica v. American Newspaper Ass'n, 130 Fed. 460 (C.C. S.D.N.Y. 1904) ; Universal Pictures Co. v. Harold Lloyd Corp., 162 F.2d 354 (9th Cir. 1947); Dam v. Kirk La Shelle Co., 166 Fed. 589 (C.C.S.D N.Y. 1908) ; Millstein v. Leland Hayward, Inc., 10 F.R.D. 198 (S.D.N.Y. 1950).

71. Lowenfels v. Nathan, 2 F. Supp. 73 (S.D. N.Y. 1932); Shipman v. RKo Radio Pictures, 20 F. Supp. 249 (S.D.N.Y. 1937), aff'd, 100 F.2d 533 (2d Cir. 1938); Fendler v. Morosco, 253 N.Y. 281, 171 N.E. 56 (1930); London v. Biograph Co., 231 Fed. 696 (2d Cir. 1916); Maxwell v. Goodwin, 93 Fed. 665 (C.C. Ill. 1899); Dymow v. Bolton, 11 F.2d 690 (2d Cir. 1926); Rose v. Connelly, 38 F. Supp. 54 (S.D.N.Y. 1941); Hewitt v. Coward, 180 Misc. 1005, 41 N.Y.S.2d 498 (Sup. Ct. 1943). Contra: John W. Shaw Advertising v. Ford Motor Co., 112 F. Supp. 121 (D. Ill. 1953), but the cases cited therem do not support the conclusion. See Asbill and Snell, Summary Judgment, 51 Mrce. L. Rev. 1143, 1145 (1953) ; cf. Arnstem v. Porter, 154 F.2d 464 (2d Cir. 1946).

72 Golding v. RKO Radio Pictures, 35 Cal.2d 690, 221 P.2d 95 (1950); Weitzenkorn v. Lesser, 40 Cal.2d 778, 256 P.2d 947 (1953).

7335 Cal.2d 690, 695, 221 P.2d 95, 97 (1950). 
make a comparison of the two works, and such comparison is of value only if it is based upon a correct determination of the issue as to the extent and nature of the plaintiff's protectible interest.

Property rights having been determined, such comparison then may be made applying the standard of the average observer "without [further] dissection and without expert or elaborate analysis," 74 i.e., is it reasonable to conclude that an average observer would believe that the form and manner of expression, the development, treatment and sequence of incidents in plaintiff's work appears in some substantial measure in defendant's work? Unless such conclusion is reasonable, plaintiff has no case as a matter of law, as was found to be the situation in Weitzenkorn and Burtis. ${ }^{75}$

If the court believes the average observer might find substantial similarity as to what has been determined to be protectible, it is its duty to present that issue to the jury. Because, however, the issue is limited to similarity in protectible property, the court must advise the jury specifically as to what such property is, or at least what is not protectible; this again emphasizes the necessity for instructions directed to specific elements in the works themselves, not to abstract general statements. In the Stanley case, Justice Carter suggested that if any similarities whatsoever existed, whether in protectible material or not, the matter should be submitted to the jury, and then if it found similarity, the court should determine whether there was similarity in protectible material. ${ }^{76}$ This is contrary to the Golding rule which requires the court first to determine protectibility, and a jury to pass only on similarities in protectible material. ${ }^{77}$ Justice Carter's error was pointed out clearly in Justice Traynor's dissent in the Stanley case ${ }^{\text {T8 }}$ and Weitzenkorn and its companion cases make it clear that the Golding approach is the proper one. If, therefore, the court makes its determination that an average observer might find similarity in protectible material, it must submit the question as to whether such similarity exists to the jury upon instructions requiring the jury to follow the same principles in the comparison of the protectible material as the court would apply on demurrer, or motion for nonsuit or directed verdict.

\section{The Issue of Copying}

Assuming the two works themselves present sufficient evidence from which to conclude that material in defendant's work is similar to some sub-

74 Burtis v. Universal Pictures Corp., 40 Cal.2d 823, 833, 256 P.2d 933, 940 (1953).

75 And more recently in Sutton v. Walt Disney Productions, 118 A.C.A. 699, 258 P.2d 519 (1953); and Palmer v. Metro-Goldwyn-Mayer, 119 A.C.A. 524, 259 P.2d 740 (1953).

7635 Cal.2d 653, 663, 221 P.2d 73, 79 (1950).

7735 Cal.2d 690, 700, 221 P.2d 95, 100 (1950).

7835 Cal.2d 653, 684, 221 P.2d 73, 91 (1950). The method proposed by Justice Carter would permit the jury to weigh similarities in material which defendant had the right to take from plaintiff's work. Such would be clearly prejudicial to defendant. 
stantial protectible property in plaintiff's work, it must still be established that defendant copied such material from plaintiff's work in order for plaintiff to recover. This means that plaintiff must prove (a) that the defendant had an opportumity to copy and (b) that having such opportunity, defendant did so. ${ }^{79}$ These are clearly factual issues, and if any substantial evidence exists in their support, they are questions for the jury.

It is imperative for plaintiff to prove the possibility of access of defendant to his work; if defendant could not have seen or heard it, he could not have copied it, and plaintiff has suffered no injury to his rights. Regardless, therefore, of the closeness of similarities some possibility of access must be shown or the court inust give judgment for defendant as a matter of law..$^{80}$

On the other hand, if such possibility appears, it is not necessary that direct evidence of access be produced. Similarities in protectible material themselves may be sufficient to infer that what was possible occurredthat defendant had access, and that he copied. ${ }^{81}$ The evidence to be weighed will normally consist on the one side of the degree of the likelihood of access and the degree of closeness of similarity, and on the other, of the denial of access and such evidence of independent authorship and of the use of other sources to account for the similarities as defendant may educe. Of course, if there are only slight similarities and the possibility of access is remote as against positive denials and convincing evidence of other available and used sources, the court may determine, as it did in Twentieth Century-Fox Film Corp. v. Dieckhaus, ${ }^{82}$ that plaintiff has not sustained his burden of proof as a matter of law. The issues being factual and the ordinary situation being one of conflict in the evidence as to the facts, the functions of judge and jury are not ordinarily complicated by reason of the nature of the subject matter.

\section{The Issue of Damages}

As in other cases, the question of damages is one for the jury's determination, the court having its usual supervisory function over the question as to inadequacy or excessiveness in the light of the evidence. As in the case of other property, plaintiff is competent to testify as to value. ${ }^{83}$

79 Barsha v. Metro-Goldwyn-Mayer, 32 Cal.App.2d 556, 90 P.2d 371 (1939).

80 Shipman v. RKO Radio Pictures Corp., 100 F.2d 533 (2d Cir. 1938) ; Sarkadi v. Wiman, 43 F. Supp. 778 (S.D.N.Y. 1942); Tamas v. Twentieth Century-Fox Film Corp., 25 N.X.S.2d 899 (Sup. Ct. 1941) ; Echevarria v. Warner Bros. Pictures Corp., 12 F. Supp. 632 (S.D. Cal. 1935); Shafter, Múvical Copyright 222 (2d ed. 1939); Warner, Radio and Television RigHTS § 155a, and cases cited n.8 (1953).

81 Barsha v. Metro-Goldwyn-Mayer, 32 Cal. App.2d 556, 90 P.2d 371 (1939); Kovacs v. Mutual Broadcasting System, 99 Cal.App.2d 56, 221 P.2d 108 (1950); Wilkie v. Santly Bros., 91 F.2d 978 (2d Cir. 1937); cf. Lewys v. O'Neill, 49 F.2d 603 (S.D.N.Y.1931).

82153 F.2d 893 (8th Cir. 1946); accord, Pinci v. Twentieth Century-Fox Film Corporation, 95 F. Supp. 884 (S.D.N.Y. 1951).

83 Stanley v. Columbia Broadcasting System, Inc., 35 Cal.2d 653, 221 P.2d 73 (1950). 


\section{CONTRACT}

Where the plaintiff and defendant have had some dealings with one another, it is usual for plaintiff to include in his complaint counts in express or "implied" contract, or both. To the extent that the "implied" contract count may be construed to allege a contract implied in law, California has held that it is governed by the same requirements as to issues and proof as the tort count for plagiarism; ${ }^{84}$ hence it needs no further discussion here. However, such count may also allege a contract implied in fact, or such an agreement may be the subject of a separate count.

The general rules as to the function of judge and jury in contract cases are too well-known to require extended discussion. The existence of a meeting of the minds and the terms thereof are questions of fact; ${ }^{85}$ the construction of any contract resulting therefrom is solely for the court. ${ }^{86}$ Whether or not the facts alleged by plaintiff to constitute a breach actually exist is for the jury; ${ }^{87}$ if so, whether they constitute a violation of contract is for the judge. ${ }^{88}$ The amount of damage is a jury question under proper instructions. ${ }^{89}$ Over all, the question of whether the evidence on any issue is sufficient for submission to the jury or to sustain a finding once made is an issue of law. ${ }^{90}$

In the case of an express contract the jury will determine factual controversies over its creation. If written the court will construe it. If its meaning depends in part on controverted extrinsic facts, such facts should be submitted to the jury on instructions posing necessary hypotheses. ${ }^{91}$ If oral, the same rules should apply; the jury finds whether an agreement was made and what its terms were; the judge construes it. It has been said that as to an oral agreement "its interpretation in the first instance was a ques-

84 Weitzenkorn v. Lesser, 40 Cal.2d 778, 256 P.2d 947 (1953) ; Kurlan v. Columbia Broadcasting System, Inc., 40 Cal.2d 799, 256 P.2d 962 (1953).

85 American Lumber Co. v. Atlantic Mill Co., 290 Fed. 632, 635 (3d Cir. 1923); Providence Jewelry Co. v. Nagel, 157 Cal. 497, 108 Pac. 312 (1910) ; Tigner v. Zosel, 172 Wash. 552, 21 P.2d 239 (1933).

86 O'Connor v. West Sacramento Co., 189 Cal. 7, 18, 207 Pac. 527, 531 (1922) ; California Well Drilling Co. v. California M. O. Co., 178 Cal. 337, 343, 177 Pac. 849, 852 (1918).

87 Sanford v. East Riverside I. Dist., 101 Cal. 275, 35 Pac. 865 (1894); Shimmon v. Moore, 104 Cal. App.2d 554, 232 P.2d 22 (1951).

S8 Pratt-Gilbert Co. v. Renaud, 25 Ariz. 79, 213 Pac. 400 (1923); Haiman v. Gundersheimer, 130 Fla. 109, 177 So. 199 (1937); Stachowitz v. Barron-Anderson Co., 121 Me. 537, 118 Atl. 378 (1922).

89 Holt Mfg. Co. v. Thornton, 136 Cal. 232, 237, 68 Pac. 708, 710 (1902) ; Parke v. Frank, 75 Cal. 364, 369, 17 Pac. 427, 429 (1888).

80 DeRemer v. Brown, 36 App. Div. 634, 55 N.Y. Supp. 367, 369 (1st Dep't 1899); Kenney v. Langston, 133 Fla. 6, 8, 182 So. 430, 432 (1938).

01 McBanne, California Triar and Appeliate Practice $\$ 524$ (1950); O'Connor v. West Sacramento Co., 189 Cal. 7, 18, 207 Pac. 527, 531 (1922). 
tion of fact to be determined by the jury," $" 92$ but it is believed this means no more than that the jury must find its terms. In the case in which such language first appears the court reversed the jury's finding on the ground that the uncontradicted terms of the oral agreement, construed by the court, could not support the judgment. ${ }^{93}$ It seems clear that the trial court should have so instructed the jury.

However, in the majority of cases it is doubtful that plaintiff can or will attempt to show any express contract relating to his work. Reliance is more usually placed on a "contract implied in fact" with an assist from "trade custom and practice." Theoretically the problem is the same, since, as Weitzenkorn says, "... The required proof is essentially the same as under the ... count upon express contract, with the exception that conduct from which the promise may be implied must be proved." ${ }^{.94}$ Practically, the function of the court becomes more difficult.

The court must initially determine whether the evidence of defendant's conduct will permit the reasonable inference that he made an agreement in fact with the plaintiff. ${ }^{95}$ The burden of proof is on the plaintiff to show each fact essential to a valid contract, including the existence of mutual intent. The circumstances must be such as to make it reasonably certain that the parties intended to and did enter into the alleged agreement. ${ }^{90}$ The conduct must be such that "looking at such conduct a reasonable person would recognize that the same pointed only to the contract." 97

Where plaintiff offers to defendant a work contaiming protectible material, ostensibly for sale; and defendant uses that protectible material, an inference of an agreement in fact to pay therefore might be found, ${ }^{08}$ in the absence, of course, of evidence negativing such agreement..$^{90}$ In such case plaintiff could recover in tort or quasi contract. The important question is presented when what defendant is alleged to have used is in fact actually nonprotectible material-either "ideas" or some other elements which may be in the public commons and incorporated in plaintiff's work.

92 Smyth v. Tennison, 24 Cal. App. 519, 521, 141 Pac. 1059, 1060 (1914); Treadwell v. Nickel, 194 Cal. 243, 260, 228 Pac. 25, 33 (1924).

93 Smyth v. Tennison, supra note 92.

9440 Cal.2d 778, 794, 256 P.2d 947, 959 (1953).

$95 \mathrm{MCBANN}$, op. cit. supra note 91 at 418 (1950).

96 Kellogg v. Gleeson, 27 Wash.2d 501, 178 P.2d 969 (1947) ; Ross v. Raymer, 32 Wash.2d 128, 201 P.2d 129 (1948).

97 Biggs \& Co. v. Lokey, 62 S.W.2d 665 (Tex. Civ. App. 1933) ; Silva v. Providence Hospital, 14 Cal.2d 762, 97 P.2d 798 (1939) ; Cammetti v. Nat'l Guar. Life Co., 56 Cal. App.2d 92, 132 P.2d 318 (1942).

98 Cf. Medina v. Van Camp Sea Food Co., 75 Cal. App.2d 551, 171 P.2d 445 (1946); Grant v. Long, 33 Cal. App.2d 725, 92 P.2d 940 (1939); Sullivan, Inc. v. Johnson, 116 Cal. App. 591, 3 P.2d 72 (1931).

99 If defendant expressly or impliedly negatives any promise, no contract can be found. Lueddecke v. Chevrolet Motor Co., 70 F.2d 345 (8th Cir. 1934); Consolidated Products Co. v. Blue Valley Creamery Co., 97 F.2d 23 (8th Cir. 1938). 
While it is conceivable that one might promise to purchase, or, in the alternative, to refrain from using, something that is readily available to him for free, it is certainly highly improbable that he would do so, as Weitzenkorn recognizes. ${ }^{100}$ It would require conduct of the nost unequivocal and affirmative nature to support as reasonable any inference of such a promise. Whether there is evidence of such conpelling force is a question of law for the court; in its absence, no contract can be found and no question exists for the jury. ${ }^{101}$

On the other hand, plaintiff may have something which, while not constituting protectible property, nevertheless is not elsewhere available for defendant's use. This would include such "ideas" as new and heretofore undisclosed business and advertising schenies and methods, slogans, trade secrets, and the like. It would also include so-called "hot ideas" for radio or television programs. Such ideas are no longer the subject of property rights in California, and any protection given them must be by express or implied in fact contract. ${ }^{102}$ Nevertheless, because of their umqueness, it will be easier to find grounds in conduct for a reasonable inference of some promise on defendant's part than in the case of material which is already otherwise freely available. Consequently it is important to determine the extent to which, if at all, the subject matter of the alleged contract is new and novel. ${ }^{103}$

10040 Cal.2d 778, 792, 256 P.2d 947, 957 (1953) ; cf. Traynor, J., dissenting in Stanley v. Columbia Broadcasting System, 35 Cal.2d 653, 674, 221 P.2d 73, 85 (1950).

101 It seems clear that the mere fact that plaintiff submits material to defendant, ostensibly for sale, and that defendant later uses unprotectible elements of such material should not be held to be substantial evidence of a contract to pay anything for such use. There is no factual basis for implying that a defendant, in examining submitted material, thereby agrees to bar himself from the use of the public commons or from the field of hiterary "ideas." Cf. Masline v. New York, etc., Ry., 95 Conn. 702, 112 Atl. 639 (1921). Where the use would not constitute a tort, it certainly should not, standing alone, constitute evidence of a contract.

102 Weitzenkorn v. Lesser, 40 Cal.2d 778, 256 P.2d 947 (1953). Under CaL. CTv. Code $\$ 980$ before its amendinent in 1947, they might be protected as "products of the mind." Stanley v. Columbia Broadcasting System, Inc., 35 Cal.2d 653, 221 P.2d 73 (1950); Kovacs v. Mutual Broadcasting System, 99 Cal. App.2d 56, 221 P.2d 108 (1950) ; cf. Kurlan v. Columbia Broadcasting System, Inc., 40 Cal.2d 799, 256 P.2d 962 (1953).

103 The cases which have assumed that the disclosure of such ideas may be protected on the theory of impled contract have generally required that they fulfill two conditions: (1) They must be new and novel; (2) they must have been reduced to concrete form. Stanley v. Columbia Broadcasting System, 35 Cal.2d 653, 221 P.2d 73 (1950); Liggett \& Myers Tobacco Co. v. Meyer, 101 Ind. App. 420, 194 N.E. 206 (1935); Larson v. General Motors Corp., 2 F.R.D. 294 (D.C.N.Y. 1948) ; Alberts v. Remington Rand, Inc., 175 Misc. 486, 23 N.Y.S.2d 892 (Sup. Ct. 1940) ; Bowen v. Yankee Network, 46 F. Supp. 62 (D. Mass. 1942); Larkin v. Penn. Rd. Co., 125 Misc. 238, 210 N.Y.Supp. 374 (Sup. Ct. 1925) ; Lueddecke v. Chevrolet Motor Co., 70 F.2d 345 (8th Cir. 1934); Moore v. Ford Motor Co., 28 F.2d 529 (S.D.N.Y. 1928). It is suggested that this is simply another way of saying that absent these two factors, no promise by defendant can reasonably be inferred. 
Whether something is new and novel is a question of fact. ${ }^{104}$ However, it is a soinewhat restricted one in that proof of prior use destroys the claim of newness or novelty. ${ }^{105}$ The court may judicially notice that certain matters are not new or novel ${ }^{106}$ or it may appear from the evidence in the case. In either event, the issue would no longer be one for jury consideration. ${ }^{107}$ If it appears to the court that the subject matter of the contract is not new and novel and if there are no highly exceptional facts which would permit the reasonable inference that defendant promised to pay for an idea, whether or not it was new or novel, then the court will direct a verdict for the defendant; otherwise the question of whether a contract was made and what its terms are is for the jury under appropriate instructions.

Whether or not any contract has been breached will ordinarily depend upon whether or not the defendant has used any material covered by its terms, and thus issues of similarity and copying already discussed are raised. In this connection, if part of the material is found by the court through judicial notice or proof not to permit the finding that it is new or novel, the jury ought to be so instructed. Where it is apparent that there was no contract to buy or refrain from using nonnovel material, it is submitted that the jury should be further charged that only similarities in novel material are to be considered. ${ }^{108}$ If the contract alleged or proved does not fairly cover such nonnovel material, and the only similarities are in that kind of material, there is no issue for the jury, as was held to be the case in Sutton v. Walt Disney Productions, Inc. ${ }^{100}$

On the issue of damages, it is also important that the jury distinguish between anything new or novel and material otherwise freely available to defendant, since the "reasonable value" which defendant has by hypothesis agreed to pay will be vastly different as to material he could secure elsewhere for nothing as compared with something wholly within plaintiff's

104 Stanley v. Columbia Broadcasting System, Inc., 35 Cal.2d 653, 221 P.2d 73 (1950); Kovacs v. Mutual Broadcasting Company, 99 Cal. App.2d 56, 221 P.2d 108 (1950).

105 Thomas v. R. J. Reynolds Tobacco Co., 350 Pa. 262, 38 Atl.2d 61 (1944); Moore v. Ford Motor Co., 28 F.2d 529 (S.D.N.Y. 1928). This is like the rule in patent cases.

${ }^{106}$ Kurlan v. Columbia Broadcasting System, Inc., 40 Cal.2d 808, 256 P.2d 962, 968 (1953); see cases cited in note 107 infra.

107 Thomas v. R. J. Reynolds Tobacco Co., 350 Pa. 262, 38 Atl.2d 61 (1944); Park-In Theatres v. Perkins, 190 F.2d 137 (9th Cir. 1951); Gasifier Corp. v. Ford Motor Co., 1 F.R.D. 10 (D.C. Mo. 1939) ; Davison Chemical Corp. v. Joliet Chemicals, 179 F.2d 793 (7th Cir. 1950).

108 This seems to follow from the language used in Kurlan v. Columbia Broadcasting System, Inc., 40 Cal.2d 799, 808-09, 810, 256 P.2d 962, 969-970 (1953). However, compare the approach in Stanley v. Columbia Broadcasting System, Inc., 35 Cal.2d 653, 663, 221 P.2d 73, 79 (1950) and the comment in Golding v. RKO Pictures, Inc., 35 Cal.2d 690, 700, 221 P.2d 95, 100-101 (1950). It is beheved that Justice Traynor's dissent in the former case on the question of the method of comparing similarities (35 Cal.2d at 683-84, 221 P.2d at 90-91) represents the present majority view.

109118 A.C. A. 699, 258 P.2d 519, hearing denied Aug. 20, 1953. 
exclusive control. Of course, it may be that the new and novel portion of the material is what gives both plaintiff's and defendant's work their entire value. On the other hand, where there is nothing new or novel, or where what there is constitutes only one factor in the value of plaintiff's submitted work, damages should be assessed accordingly. ${ }^{110}$

The contract count seems to present a most appropriate situation for the submission of special verdicts. In that way the jury could ascertain the terms of any contract and decide the factual questions of novelty, similarity and copying, if the evidence warranted submission of any or all of these issues. The court would then determine whether the evidence permitted the implication of any contract found, construe the contract and determine whether it had been breached and in what particulars. It is hoped that future cases may explore this possibility.

\section{APPENDIX}

This Appendix comprises a comprehensive, but incomplete list of reported decisions in literary plagiarism actions which deal with the issues of protectibility and similarity. The cases are limited to those involving works of bterature, such as books, plays and the like; the lists do not include those dealing with inusical compositions, works of art, text books, compilations, etc., nor do they include cases dealing with business schemes or plans, radio or television program "ideas," or similar matters ordinarily protectible only under contract principles. Neither are there included cases dealing only with other issues such as access, copyright validity, or damages. Cases involving common law rights as distinguished from statutory Copyright are designated "(CL)."

Group 1. Cases in Which No Substantial Similarity in Protectible Material Was Found. (Cases marked with an asterisk $\left(^{*}\right)$ are those in which the determination was made by the court as a clear matter of law, i.e., on motion for summary judgment, demurrer, motion for judgment on the pleadings, nonsuit, or by an appellate court's reversal of a judgment for plaintiff.) Bachman v. Belasco, 224 Fed. 817 (2d Cir. 1915); Barbadillo v. Goldwyn, 42 F.2d 881 (S.D. Cal. 1930); *Becker v. Loew's, Inc., 133 F.2d 889 (7th Cir. 1943) ; Bein v. Warner Bros. Pictures, 105 F.2d 969 (2d Cir. 1939); Burns v. Twentieth Century-Fox, 75 F. Supp. 986 (D. Mass. 1948); Cain v. Universal Pictures, 47 F. Supp. 1013 (S.D. Cal. 1942); *Caruthers v. RKO Radio Pictures, 20 F. Supp. 906 (S.D.N.Y. 1937) (CL); Christie v. Harris, 47 F. Supp. 39 (S.D.N.Y. 1942), aff'd sub nom., 154 F.2d 827 (2d Cir. 1946); Collins v. Metro-Goldwyn Pictures, 106 F.2d 83 (2d Cir. 1939); Columbia Pictures Corp. v. Krasna, 65 N.Y.S.2d 67 (Sup. Ct. 1946) (CL); Curwood v. Affiliated Distrihutors, Inc., 283 Fed. 223 (S.D.N.Y.1922); Dellar v. Samuel Goldwyn, Inc., 104 F.2d 661 (2d Cir. 1939); De Montijo v. Twentieth Century-Fox, 40 F. Supp. 133 (S.D. Cal. 1941); Dezendorf v. Twentieth Century-Fox, 32 F. Supp. 359 (S.D. Cal. 1940), aff'd, 118 F.2d 561 (9th Cir. 1941); *Dymow v. Bolton, 11 F.2d 690 (2d Cir. 1926) ; *Echevarria v. Warner Bros. Pictures, 12 F. Supp. 632 (S.D. Cal. 1935); Eichel v. Marein, 241 Fed. 404 (S.D.N.Y. 1913); *Fendler v. Morosco, 253 N.Y. 281, 171 N.E. 56 (1930) (CL) ; Frankel v. Irwin, 34 F.2d 142 (S.D.N.Y. 1918) ; Funkhouser v. Loew's Inc., 108 F. Supp. 476 (W.D. Mo. 1952) (CL); Gropper v. Warner Bros. Pictures, 38 F. Supp. 329 (S.D. N.Y.1941); Hewitt v. Coward, 180 Miss. 1065, 41 N.Y.S.2d 498 (Sup. Ct. 1943) (CL);

110 There are several interesting questions as to the proper mcasure of defendant's recovery on a contract count. For example, the value to defendant of the use may differ substantially in amount from the loss suffered by plaintiff through such use, and the question immediately presents itself as to what "reasonable value" defendant impliedly agreed to pay. Such questions are, however, beyond the scope of this discussion. 
*Heywood v. Jericho Co, 193 Misc. 905, 85 N.Y.S.2d 464 (Sup. Ct. 1948) (CL); Kustoff v. Chaplin, 120 F.2d 551 (9th Cir. 1941) ; Lewys v. O'Neill, 49 F.2d 603 (S.D.N.Y. 1931); *Lloyd Corporation v. Witwer, 65 F.2d 1 (9th Cir. 1933); *London v. Biograph Co., 231 Fed. 696 (2d Cir. 1916); *Lowenfels v. Nathan, 2 F. Supp. 73 (S.D.N.Y. 1932); Lynch v. Warner Bros. Pictures, 32 F. Supp. 575 (S.D.N.Y. 1940) (CL); MacDonald v. Du Maurier, 75 F. Supp. 655 (S.D.N.Y. 1948); Maddux v. Grey, 43 F.2d 441 (S.D.Cal. 1930) ; *Maxwell v. Goodwin, 93 Fed. 665 (C.C.N.D.III. 1899) (CL) ; McConnor v. Kaufman, 49 F. Supp. 738 (S.D.N.Y. 1943) (CL) ; *Millstein v. Leland Hayward, Inc., 10 F.R.D. 198 (S.D.N.Y. 1950); Nichols v. Universal Pictures, 34 F.2d 145 (S.D.N.Y. 1929), aff'd, 45 F.2d 119 (2d Cir. 1930); *Ornstcin v. Paramount Productions, 9 F. Supp. 896 (S.D.N.Y. 1935); O'Rourke v. RKO Radio Pictures, 44 F. Supp. 480 (D. Mass. 1942) (CL); *Palmer v. Metro-Goldwyn-Mayer Pictures, 119 A.C. A. 524, 259 P.2d 740 (1953); Pinci v. Twentieth Century-Fox Filn Corp., 95 F. Supp. 884 (S.D. N.Y. 1951) ; Prior v. Schuman, 106 F. Supp 469 (S.D.N.Y. 1952) (CL) ; Roe-Lawton v. Hal E. Roach Studios, 18 F.2d 126 (S.D. Cal. 1927); *Rose v. Connelly, 38 F. Supp. 54 (S.D. N.Y. 1941); Rush v. Oursler, 39 F.2d 468 (S.D.N.Y.1930); Sarkadi v. Wiman, 135 F.2d 1002 (2d Cir. 1943) ; Schwarz v. Universal Pictures Corp., 85 F. Supp. 270 (S.D. Cal. 1945) (CL) ; Shipman v. RKO Radio Pictures, 100 F.2d 533 (2d Cir. 1938); Simonton v. Gordon, 297 Fed. 625 (S.D.N.Y.1924) (preliminary injunction demed), 12 F.2d 116 (S.D.N.Y.1925) (decree granted); Solomon v. RKO Radio Pictures, 44 F. Supp. 780 (S.D.N.Y. 1942); Stevenson v. Harris, 238 Fed. 432 (S.D N.Y. 1917) ; *Sutton v. Walt Disney Productions, 118 A.C.A. 699, 258 P.2d 519 (1953); *Twentieth Century-Fox v. Dieckhaus, 153 F.2d 893 (8th Cir. 1946); Underhill v. Belasco, 254 Fed. 838 (S.D.N.X.1918); Vernon v. Schubert, Inc., 220 Fed. 694 (S.D.N.Y.1915); *Weitzenkorn v. Leśser, 40 Cal.2d 778, 256 P.2d 947 (1953).

Cf. Golding v. RKO Radio Pictures, 35 Cal.2d 690, 221 P.2d 95 (1950); West v. Hatch, 49 F. Supp. 307 (S.D.N.Y. 1943); *Wiren v. Shubert Theatre Corp., 5 F. Supp. 358 (S.D. N.X.1933).

Group 2. Cases in Which Substantial Similarity in Protectible Material Was Found. (Cases where defendants "pirated," or exactly copied, plaintiff's work are not included.)

Barsha v. Metro-Goldwyn-Mayer, 32 Cal. App.2d 556, 90 P.2d 371 (1939) (CL) ; Casino Productions v. Vitaphone Corp., 163 Misc. 403, 295 N.Y.Supp. 501 (Sup. Ct. 1937) (CL); Chappell \& Co. v. Ficlds, 210 Fed. 864 (2d Cir. 1914); Daly v. Palmer, 6 Fed. Cas. 1132, No. 3,552 (C.C.S.D.N.Y. 1868); cf. Daly v. Webster, 56 Fed. 483 (2d Cir. 1892); Dam v. Kirk LaShelle Co., 175 Fed. 902 (2d Cir. 1910) ; De Acosta v. Brown, 146 F.2d 408 (2d Cir. 1944); Detective Comics v. Bruns Publications, 111 F.2d 432 (2d Cir. 1940); International Film Service Co. v. Affiliated Distributors, Inc., 283 Fed. 229 (S.D.N.Y.1922); O'Neill v. General Film Co., 157 N.Y. Supp. 1028 (1st Dep't 1916) ; Sheldon v. Metro-Goldwyn Pictures, 81 F.2d 49 (2d Cir. 1936); Stephens v. Howells Sales Co., 16 F.2d 805 (S.D.N.Y.1926); Stodart v. Mutual Film Corp., 249 Fed. 507 (S.D.N.Y. 1917); Twenticth Century-Fox v. Stonesifer, 140 F.2d 579 (9th Cir. 1944); Universal Pictures Corp. v. Harold Lloyd Corp., 162 F.2d 354 (9th Cir. 1947); Yadkoe v. Fields, 66 Cal. App.2d 150, 151 P.2d 906 (1944) (CL). 